\title{
ASSESSMENT OF ENVIRONMENTAL IMPACT FROM RENEWABLE AND NON-RENEWABLE ENERGY SOURCES
}

\author{
M. RAGAZZI ${ }^{1}$, G. IONESCU ${ }^{2} \&$ S.I. CIORANU ${ }^{2}$ \\ ${ }^{1}$ University of Trento, Civil, Environmental and Mechanical Department, Trento, Italy. \\ ${ }^{2}$ Politehnica University of Bucharest, Department of Energy Production and Use, Bucharest, Romania.
}

\begin{abstract}
The scientific studies show that the greatest amount of $\mathrm{CO}_{2}$ emissions, in the European Union, results from the production of electricity and heat (for example, the production of coal-based energy in the EU Member States generates an amount of approximately one billion tons of $\mathrm{CO}_{2}$ emissions, that is about $1 / 4$ of total $\mathrm{CO}_{2}$ emissions in the EU). The waste sector is a significant contributor to greenhouse gas (GHG) emissions accountable for approximately one twentieth of the global greenhouse budget. This contribution consists of $\mathrm{CH}_{4}$ emission from waste anaerobic decomposition and $\mathrm{CO}_{2}$ from thermal treatments. This study presents some district heating preliminary considerations through thermo-chemical conversion of renewable and non-renewable sources. Three locations are virtually analyzed, two counties from Romania and one from Italy. A comparison is made between using different potential types of fuel: wood, coal, MSW, residual municipal solid waste (RMSW), bio-dried waste (BD) and solid-recovered fuel (SRF). The lower heating values (LHVs) of the two types of studied lignite (coal from Romania and Italy) are higher in comparison with the LHV of MSW, similar to the ones of RMSW and BD waste, but lower to the ones of SRF and wood, with some exceptions. Data suitable for preliminary global environmental balances and local impact considerations from atmospheric emissions were carried out for the quantity of primary fuel as presented. Results demonstrate that, even from the preliminary considerations, the environmental performances of district heating are strongly affected by the choice of the fuel.
\end{abstract}

Keywords: air emissions, biomass, combustion, $\mathrm{CO}, \mathrm{CO}_{2}, \mathrm{LHV}, \mathrm{SO}_{2}$, waste.

\section{INTRODUCTION}

The greatest amount of $\mathrm{CO}_{2}$ emissions, in the European Union, results from the production of electricity and heat. For example, the production of coal-based energy in the EU Member States reached an amount of approximately one billion tons of $\mathrm{CO}_{2}$ emissions one decade ago, equivalent to $24 \%$ of total $\mathrm{CO}_{2}$ emissions in the $\mathrm{EU}[1,2]$.

The waste sector is a significant contributor to greenhouse gas (GHG) emissions accountable for approximately 5\% of the global greenhouse budget. This 5\% consist of methane $\left(\mathrm{CH}_{4}\right)$ emission from waste anaerobic decomposition and a fraction of carbon dioxide $\left(\mathrm{CO}_{2}\right)$ from thermal treatments [3]. $\mathrm{CO}_{2}$ from aerobic and anaerobic biological processes is not accounted in the balances as biomass (even wasted biomass) is considered a renewable source of energy.

At the moment, landfilling remains the primary waste disposal strategy internationally. As result of the modernization of the sector, many countries have been incorporating alternative forms of waste management strategies such as [4-9].

- Energy recovery from landfill gas capture.

- Bio-stabilization of waste prior to landfilling (to reduce fugitive emissions of methane).

- Composting/anaerobic digestion of the organic fraction of municipal solid waste (OFMSW).

- Waste thermal treatments with energy recovery. 
The efficiency of municipal solid waste (MSW) selective collection (SC) has an important role in potential waste recovery by reducing the residual municipal solid waste (RMSW) stream and increasing its specific heating value [10]. From the energy point of view, however, SC decreases the overall energy content of RMSW. Depending on its properties, the RMSW can be subjected to an advanced mechanical and biological treatment and the final product can be classified as solid-recovered fuel (SRF), a sustainable alternative as a fraction of this product can be seen as renewable.

In the light of the above, this paper analyses, preliminarily, potential heating by thermo-chemical conversion of renewable and non-renewable sources.

Three locations were analyzed: two counties from Romania and one province from the North of Italy. A preliminary comparison is made between using different types of fuel: wood, coal, RMSW, bio-dried waste (BD) and SRF.

First of all, it is analyzed the possibility of reducing or replacing fossil fuels (non-renewable sources) for energy production (thermal and electric) with sources partially renewable like RMSW. The reference solution is to implement combustion fed by waste. Moreover, the possibilities to couple incineration plants with bio-drying plants, which will produce SRF after post-treatment, are taken into consideration. An estimation of lower heating value (LHV) using indirect methods was performed based on the ultimate composition of each fraction of the analyzed fuel types. Calculations of analyzed fuels combustion were carried out along with global environmental balances.

\section{MATERIALS AND METHODS}

Three cases have been selected in order to get data on the availability of waste suitable for energy recovery. Moreover, the cases have been selected as related to areas where district heating is locally interesting because of their climatology. The quantities of MSW and RMSW generated in these three regions are determined taking into account the population: about 605,000 inhabitants in the province of Trento (Italy), about 425,000 and 400,000 inhabitants in the Vâlcea and Sibiu Counties, respectively (Romania) [11, 12]. The waste management system of each region was taken into account. The MSW and RMSW stream generation in the studied areas are presented in Fig. 1 according to recent data.

The available woody biomass from forestry and wood processing industry in Sibiu County and Vâlcea County is about $140,000 \mathrm{t} \mathrm{y}^{-1}$ and 150,000 $\mathrm{t} \mathrm{y}^{-1}$, respectively, and can be used for generating thermal and/or electric energy [11]. The Province of Trento is of reference when it comes to understanding the role of wood combustion along the Alps. Here, the present energy demand covered by wood is around the following values: 107.5

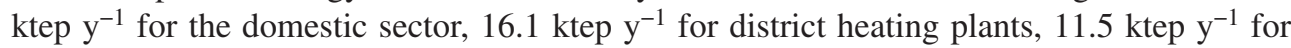
other activities (pizzerias included). The domestic sector uses about 444,000 t y ${ }^{-1}$, (assumed with a reference moisture as a standard) of a large variety of wood; each one has its own characteristics [13].

An estimation of LHV using indirect methods was performed based on the ultimate composition of each fraction of the analyzed fuel types as presented in Fig. 2 [14-16].

The bio-drying process was considered to be applied to the RMSW in the proposed case-studies in order to obtain BD and an SRF obtained from BD taking out the inert, glass and metal fractions $[17,18]$.

The determination of the LHV has been done by using the next empirical equation [19].

$$
\mathrm{LHV}=81 C+342.5(\mathrm{H}-\mathrm{O} / 8)+22.5 \mathrm{~S}-6(9 \mathrm{H}-\mathrm{W})\left[\mathrm{kcalkg}^{-1}\right]
$$




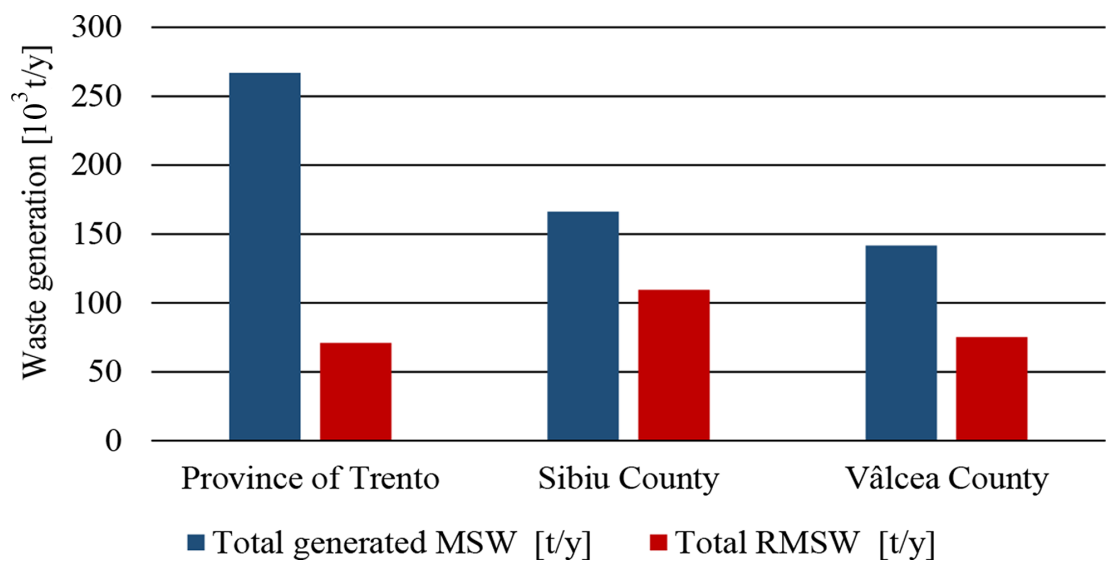

Figure 1: MSW and RMSW streams in the regions studied.

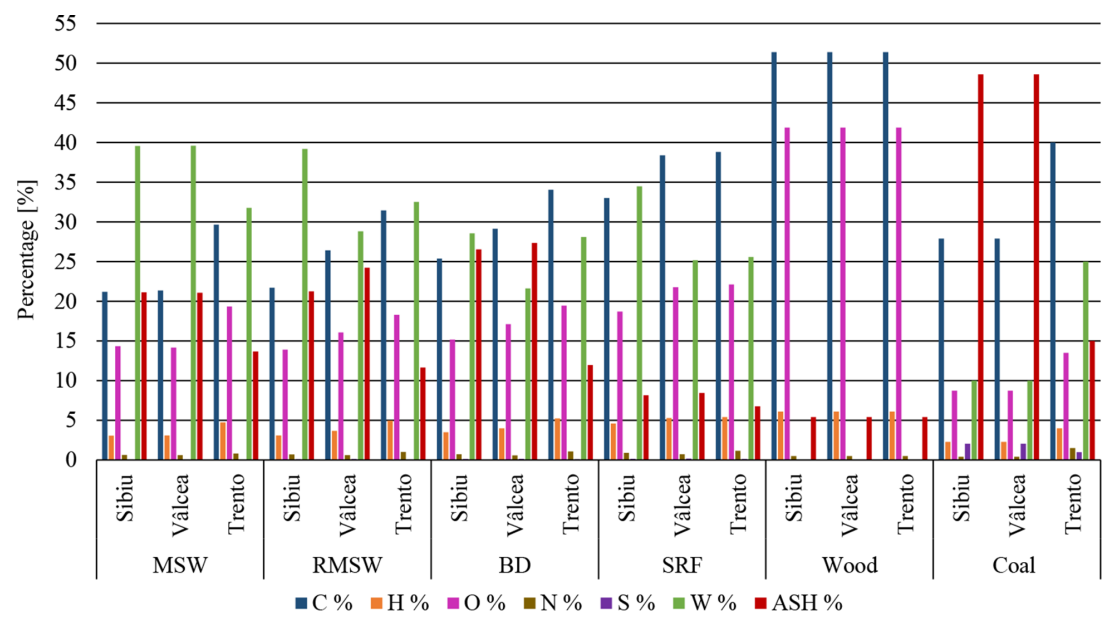

Figure 2: Elemental composition of the MSW, RMSW, BD, SRF, wood and coal by region (coal refers to a kind of coal locally suitable).

The environmental balances were performed based on the LHVs of the analyzed fuels. Thus, the emission factors for carbon dioxide $\left(\mathrm{CO}_{2}\right)$, carbon monoxide $(\mathrm{CO})$, sulphur dioxide $\left(\mathrm{SO}_{2}\right)$ and ash (A) were calculated using eqns (2)-(6).

$$
\begin{aligned}
e_{\mathrm{co}_{2}}= & \frac{\frac{M_{\mathrm{co}_{2}}}{M_{c}} \frac{C}{100}}{H_{i}^{i}}\left[\mathrm{~kg} \mathrm{kj}^{-1}\right] \\
e_{c o}= & \frac{\frac{M_{c o}}{M_{c}} \frac{C}{100}}{H_{i}^{i}} \cdot k\left[k g ~ k j^{-1}\right]
\end{aligned}
$$




$$
\begin{gathered}
\mathrm{e}_{\mathrm{so}_{2}}=\frac{\frac{\mathrm{M}_{\mathrm{So}_{2}}}{\mathrm{M}_{\mathrm{S}}} \frac{\mathrm{S}}{100}}{\mathrm{H}_{\mathrm{i}}^{\mathrm{i}}}(1-\mathrm{r})\left[\mathrm{kg} \mathrm{kj}^{-1}\right] \\
\mathrm{e}_{\mathrm{ash}}=\frac{\mathrm{A}^{*}(1-\mathrm{X}) *(1-\mathrm{Y})}{\mathrm{H}_{\mathrm{i}}^{\mathrm{i}}}\left[\mathrm{kg} \mathrm{kj}^{-1}\right] \\
\mathrm{E}_{\mathrm{i}}=\mathrm{B} * \mathrm{LHV}^{*} \mathrm{e}_{\mathrm{i}}\left[\mathrm{kg} \mathrm{s}^{-1}\right]
\end{gathered}
$$

where:

$\mathrm{C}=$ fuel carbon content $(\%)$.

$\mathrm{S}=$ fuel sulphur content $(\%)$.

$\mathrm{M}_{\mathrm{CO} 2}=$ molecular mass of carbon dioxide $=44$.

$\mathrm{M}_{\mathrm{SO} 2}=$ molecular mass of sulphur dioxide $=64$.

$\mathrm{M}_{\mathrm{CO}}=$ molecular mass of carbon dioxide $=28$.

$\mathrm{M}_{\mathrm{C}}=$ molecular mass of carbon $=12$.

$\mathrm{M}_{\mathrm{S}}=$ molecular mass of sulphur $=32$.

$\mathrm{Hi}=$ fuel lower heating value $[\mathrm{kg} / \mathrm{kJ}]$.

$\mathrm{W}=$ water content.

$\mathrm{k}=$ coefficient that takes into account the quality of combustion.

$\mathrm{r}=$ degree of sulfur retention in slag and ash $=0.2$.

$\mathrm{A}=$ fuel ash content $(\%)$.

$\mathrm{x}=$ degree of ash retention into the furnace $(\%)=0.15$.

$\mathrm{y}=$ dust collection installation efficiency $(\%)=0.98$.

$\mathrm{E}_{\mathrm{i}}=$ emission for element $\mathrm{i}\left[\mathrm{kg} \mathrm{s}^{-1}\right]$.

$\mathrm{B}=$ fuel flow $\left[\mathrm{kg} \mathrm{s}^{-1}\right]$.

$\mathrm{LHV}=$ fuel lower heating value $\left[\mathrm{kJ} \mathrm{kg}^{-1}\right]$.

$\mathrm{ei}=$ emission factor for element $\mathrm{i}\left[\mathrm{kg} \mathrm{kJ}^{-1}\right]$.

\section{RESULTS}

Based on the ultimate analysis of each fraction of the analyzed fuel types, an estimation of LHV using indirect methods was performed. From an energy point of view, the conducted calculation regarding LHV predictions highlights the fact that the LHV of generated waste in the Italian case is higher than the ones generated in the Romanian cases for all considered fractions (MSW, RMSW, BD, SRF) as presented in Fig. 3. The main reasons are the elemental composition of waste fractions, their percentage in waste and the role of SC. SC in the Italian case overcomes the $65 \%$ value, being almost double than in the Romanian cases. Its effect is an indirect concentration of energy in the RMSW.

When comparing the LHV of wood/wood residues on a dry basis with the one of wastes, we can state that it is higher than the ones of MSW, RMSW, BD and SRF. This applies for all three regions, only with two exceptions: the LHVs for SRF in the Italian case and in one of the Romanian cases are close to the one of wood/wood residues. This is the positive effect of RMSW pre-treatment. The LHVs of the two types of studied lignite (coal from Romania and Italy) are higher than LHV of MSW, similar to the ones of RMSW and BD, but lower than the ones of SRF and wood, with some exceptions. That depends on the quality of coal, which can vary a lot depending also on the market of reference. 


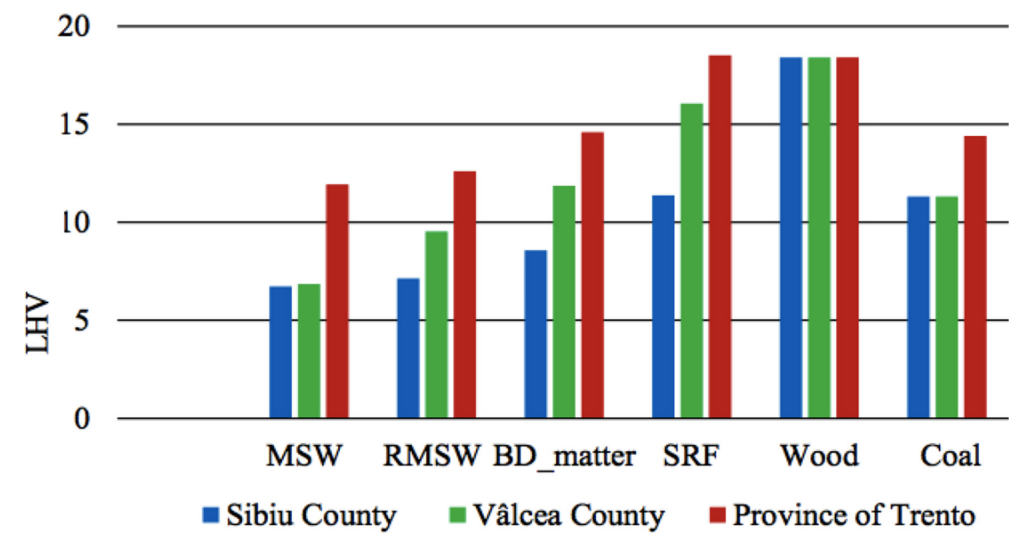

Figure 3: Estimation of the LHV by type of material $[\mathrm{MJ} / \mathrm{kg}]$.

It must be pointed out that the quality of combustion is strongly affected by the choice of fuel: as expected, coal would be the worst solution if we look at the expected emission factors shown in Fig. 4. This behavior makes coal less and less interesting for civil uses. For example, in the region of Trento, coal is authorized only for industrial uses in the sector of building products generation, while a civil use is no longer accepted.

The preliminary approach adopted in this article cannot analyze specific problems pointed out for wood: its combustion generates a significant number of ultrafine particles compared to other options; their impact can be significant even if the released mass is negligible.

Global environmental balances and preliminary local calculations for atmospheric emissions were carried out for the quantity of fuel as presented in Table 1. Data refers to a virtual combustor able to exploit all the RMSW of each area. Wood emissions have been managed as from the sector (not only district heating).

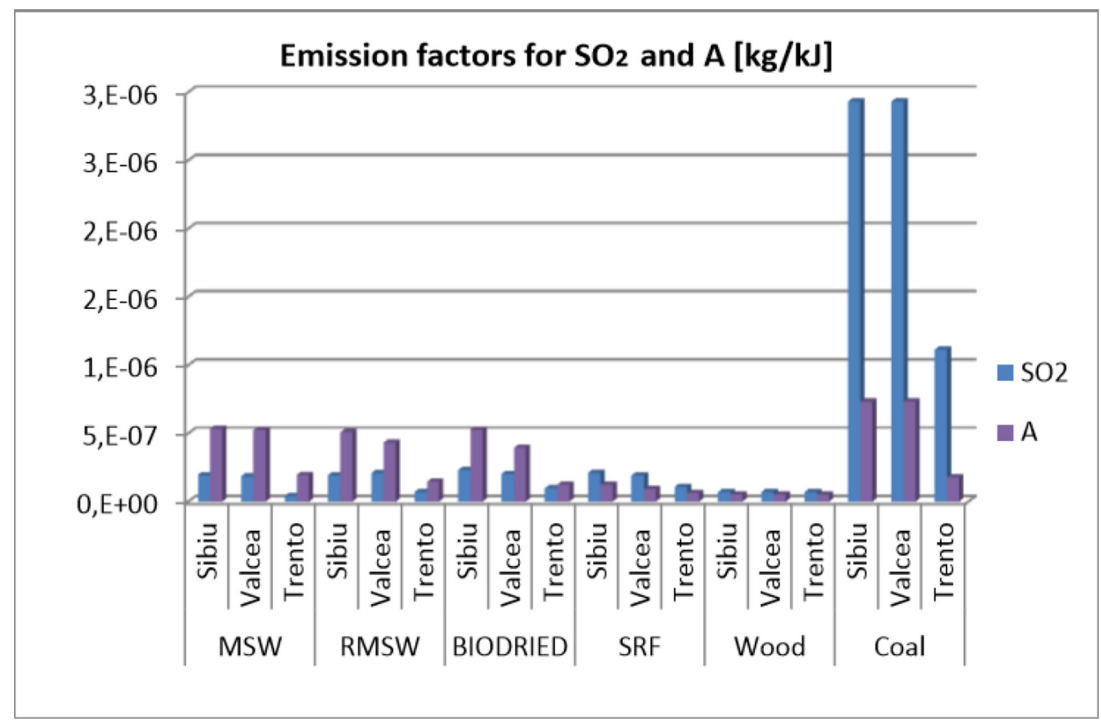

Figure 4: $\mathrm{SO}_{2}$ and dust (ash)-specific emissions. 
Table 1: Fuel inflow in the virtual combustors for RMSW.

\begin{tabular}{lllll}
\hline Indicator & Unit & Case 1 (Sibiu) & Case 2 (Vâlcea) & Case 3 (Trento) \\
\hline Waste feed in flow & {$\left[\mathrm{kg} \mathrm{s}^{-1}\right]$} & 3.92 & 2.71 & 3.67 \\
\hline
\end{tabular}

Coal has been removed as hypothesis because of its low environmental performances.

Some of the overall results on the emissions, considering the above-presented scenarios are shown in Figs 5 and 6.

More in general, from the calculated emissions of the studied fuels in the three locations, the following statements can be made.

- The emissions of $\mathrm{CO}_{2}$ are four times higher from the sector of wood than the one of waste, but wood accounts for zero, while waste (even pre-treated) gives a contribution always higher than zero even if it is pre-treated; moreover, the renewable fraction of RMSW, BD and SRF varies depending on the composition; in Italy, the approach is simplified assum-

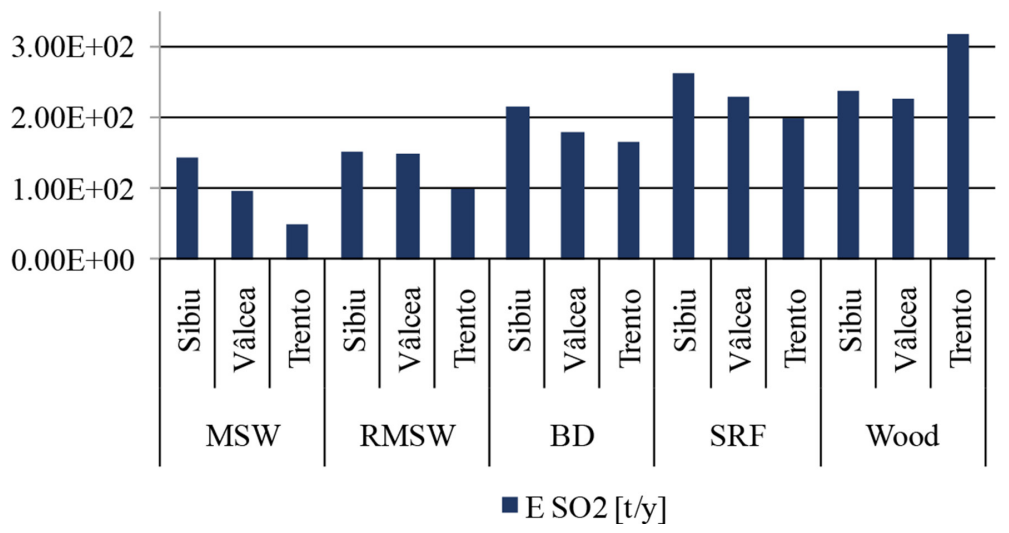

Figure 5: $\mathrm{SO}_{2}$ annual emissions.

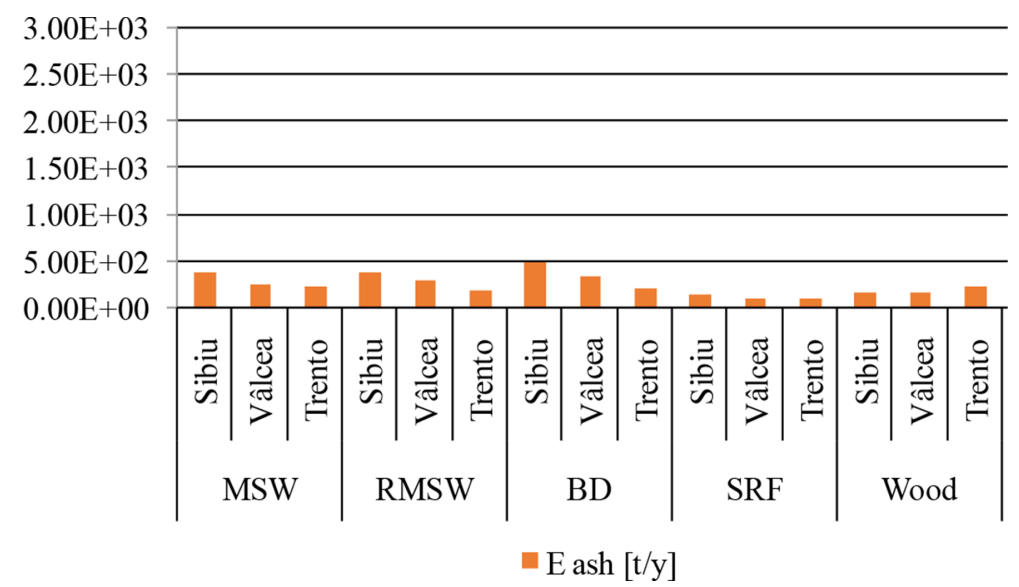

Figure 6: Ash (dust) annual emissions. 
ing a percentage of 51\%; the consequent $\mathrm{CO}_{2}$ emission can be compared with the one from the average of the national plants (mix of fuels) in order to assess how waste to energy options are clean; the recent trend in many European Countries toward methane and renewable sources as input of the energy plants makes more and more unfavorable the comparison of the waste combustion sector. A deeper analysis of the role of $\mathrm{N}_{2} \mathrm{O}$ in the emissions would demonstrate that it is negligible in the overall balances of equivalent $\mathrm{CO}_{2}$.

- Co-generation coupled with district heating plays a different role if we consider the national political strategies for incentives related to biomass; in case of absence of incentives for electricity from biomass-like fuels (e.g. RMSW or SRF) the cost for generating a unit of energy from waste combustion can be lowered increasing the capacity of the plant (scale effect); as a consequence there will be a concentration of emissions in a reduced number of sites; that can be managed increasing the capital costs of the off-gas treatment line; the risk is an overall increase of the costs of treatment that makes waste to energy less interesting than biomass to energy options.

- Data in Fig. 5 demonstrate that the waste sector can manage $\mathrm{SO}_{2}$ emissions reducing that at levels typical of a natural fuel (wood).

- Data in Fig. 6 show that the sector of wood could be considered not critical for dust emissions; in reality, the granulometry of dust in this case is unfavorable; specific solutions for its management at local level should be performed.

- The traceability of waste in Europe is more clear than wood; the consequence is that contaminated wood industrially produced from contaminated soils could reach biomass plants that have a limited ability to remove micro-pollutants from off-gas.

- The flexibility of plant capacity in the sector of wood (suitable also for small plants) opens to the construction of district heating plants also in mountain areas where the local climatology can be critical. In this case, the approach based on emission factors can be tricky: a local analysis should be compulsory before an authorization even at small scale.

- Because of the bio-drying process, the LHV of the waste can improve making it appropriate co-generation in fluid bed for energy recovery (thermal and electric). Fluid bed is a well-known high-quality combustor; however, it must be remembered that even bio-drying has emissions to be accounted in the balances.

\section{CONCLUSIONS AND OUTLOOKS}

The possibility of reducing or replacing fossil fuels (non-renewable sources) with (partially) renewable ones, such as MSW, RMSW or SRF has been taken in consideration. In order to comply with the recent EU regulations, the Province/Counties of Trento, Sibiu and Vâlcea Counties implemented/are modifying solid waste management systems. The objective is to minimize as much as possible the quantity of MSW that is landfilled and encourage SC, material recycling, waste-to-energy technologies and waste treatment before disposal through landfill. From an energy point of view, the conducted calculation regarding LHV predictions highlights the fact that the lower calorific value of generated waste in Province of Trento is higher as against the ones for generated waste in Sibiu and Vâlcea Counties. This fact is true for all the studied choices - MSW, RMSW, BD and SRF. The main reason is the elemental composition of waste fractions and their percentage in waste. Moreover, the calorific value of waste can be affected by the solid waste management system, namely the performance of SC. $\mathrm{SC}$ in Province of Trento has overcome the target value of $65 \%$, which is about double than the percentage of SC in Sibiu and Vâlcea Counties. The wood sector is interesting in terms of global balances but need particular attention in terms of local environmental impact. 


\section{ACKNOWLEDGMENTS}

This paper work has been partially funded by Erasmus+ under financial agreement 2014-1-RO01-KA203-002986.

\section{REFERENCES}

[1] Ionescu, G. \& Stefani, P., Environmental assessment of waste transport and treatment: a case study. WIT Transactions on Ecology and the Environment, 180, pp. 175-185, 2014. http://dx.doi.org/10.2495/WM140151

[2] Cioca, L.I., Ivascu, L., Rada, E.C., Torretta, V. \& Ionescu, G., Sustainable development and technological impact on $\mathrm{CO}_{2}$ reducing conditions in Romania. Sustainability, 7(2), pp. 1637-1650, 2015. http://dx.doi.org/10.3390/su7021637

[3] Monlau, F., Sambusiti, C., Antoniou, N., Barakat, A. \& Zabaniotou, A., A new concept for enhancing energy recovery from agricultural residues by coupling anaerobic digestion and pyrolysis process. Applied Energy, 148, pp. 32-38, 2015. http://dx.doi.org/10.1016/j.apenergy.2015.03.024

[4] Rada, E.C., Ragazzi, M., Ionescu, G., Merler, G., Moedinger, F., Raboni, M. \& Torretta, V., Municipal solid waste treatment by integrated solutions: energy and environmental balances. Energy Procedia, 50, pp. 1037-1044, 2014. http://dx.doi.org/10.1016/j.egypro.2014.06.123

[5] Torretta, V., Ionescu, G., Raboni, M. \& Merler, G., The mass and energy balance of an integrated solution for municipal solid waste treatment. WIT Transactions on Ecology and the Environment, 180, pp. 151-161, 2014. http://dx.doi.org/10.2495/WM140131

[6] Ionescu, G., Rada, E.C., Ragazzi, M., Mărculescu, C., Badea, A. \& Apostol, T., Integrated municipal solid waste scenario model using advanced pretreatment and waste to energy processes. Energy Conversion and Management, 76, pp. 1083-1092, 2013. http://dx.doi.org/10.1016/j.enconman.2013.08.049

[7] Marculescu, C. \& Alexe, F., Assessing the power generation solution by thermal-chemical conversion of meat processing industry waste. Energy Procedia, 50, pp. 738-743, 2014. http://dx.doi.org/10.1016/j.egypro.2014.06.091

[8] Patrascu, R., Minciuc E., Tutica D., Norisor M., Ionescu G. \& Stefani P., Reducing environmental impact through efficient utilisation of biomass in a cogeneration plant. case study - energy supply of an industrial company through biomass utilisation in a cogeneration plant with internal combustion engine. Quality - Access to Success, 15(138), pp. 84-88, 2014.

[9] Cioca, L.I. \& Ivascu, L., Characterization of automotive shredder residues before and five years after landfill disposal. Revista Ambiente e Agua, 10(2), pp. 253-262, 2015. http://dx.doi.org/10.4136/ambi-agua.1570

[10] Ionescu, G., Rada, E.C. \& Cioca, L.I., Municipal solid waste sorting and treatment schemes for maximizing material and energy recovery in a latest EU member. Environmental Engineering and Management Journal, 14(11), pp. 2501-2746, 2015.

[11] Ciudin, R., Isarie, C., Cioca, L., Petrescu, V., Nederita, V. \& Ranieri, E., Vacuum waste collection system for an historical city center. UPB Scientific Bulletin, Serie D, 76(3), pp. 209-216, 2014. 
[12] Provincia Autonoma di Trento (PAT), Piano Energetico AmbientaleProvinciale 2013/2020.

[13] National Forest Administration, Romania (NFRA), available at: http://www.rosilva.ro/ categorie.php?idL'4, (accessed 2014).

[14] Apostol, T. \& Mărculescu, C., Managementul Deşeurilor Solide, ed. Agir, Bucharest, 2006.

[15] Barbone, F., Brevi, F., Ghezzi, U., Ragazzi, M. \& Venturi, A., Studio Fatibillita - Concessione di lavori per la progettazione, realizzazione e gestione dell'impianto di combustione o altrotrattamentotermico con recupero energetico per rifiutiurbani e speciali assimilabili in località Ischiapodetti, nel comune di Trento, 2009.

[16] Francescato, V. \& Antonini, E., Supporting the organization of spot markets supply for wood chips and firewood, 2010, available at: http://ec.europa.eu/

[17] Rada, E.C., Ragazzi, M. \& Badea, A., MSW bio-drying: design criteria from 10 years research. UPB Scientific Bulletin, serie D, 74(3), pp. 209-216, 2012.

[18] Velis, C.A., Wagland, S., Longhurst, P., Robson, B., Sinfield, K., Wise, S. \& Pollard, S., Solid recovered fuel: materials flow analysis and fuel property development during the mechanical processing of biodried waste. Environmental Science and Technology, 47(6), pp. 2957-2965, 2013.

http://dx.doi.org/10.1021/es3021815

[19] Kathiravale, S., Yunus, M.N.M., Sopian, K., Samsuddin, A.H. \& Rahman, R.A., Modeling the heating value of municipal solid waste. Fuel, 82(9), pp. 1119-1125, 2003. http://dx.doi.org/10.1016/S0016-2361(03)00009-7 